\title{
COMPARATIVE RADIOCARBON DATING OF LIGNITE, POTTERY, AND CHARCOAL SAMPLES FROM BABELDAOB ISLAND, REPUBLIC OF PALAU
}

\author{
Atholl Anderson ${ }^{1} \bullet$ John Chappell • Geoffrey Clark • Sarah Phear \\ Centre for Archaeological Research, Australian National University, Canberra ACT 0200, Australia.
}

ABSTRACT. It is difficult to construct archaeological chronologies for Babeldaob, the main island of Palau (western Micronesia), because the saprolitic clays of the dominant terraced-hill sites and associated ceramic sherds often contain old carbon that originated in lignites. This has implications, as well, for chronologies of sedimentary sequences. Comparative analysis of the dating problem using lignite, pottery, and charcoal samples indicates that, in fact, there are both old and young sources of potential contamination. It is concluded that radiocarbon samples from Babeldaob need to be tested for appropriate carbon content rather than relying solely upon material identification.

\section{INTRODUCTION}

The chronology of prehistoric colonization in the west Micronesian archipelago of Palau remains uncertain (Wickler 2001a). In part, at least, this has arisen from variation in research strategies. Palau is divided into two geographical provinces: the northern basalt island of Babeldaob and the southern limestone "rock islands." Archaeological research has tended to focus upon one or the other, and to sample, consequently, different site types, preservation environments, and stratigraphic situations. Working mainly on the rock islands, Masse (1990) estimated the age of initial colonization as about $2000 \mathrm{BP}$, while the extensive Compact Road project on Babeldaob (Wickler et al. 1997; Wickler 1998; Liston et al. 1998; Liston 1999; Welch 2001) has produced possible archaeological data extending to about $3400 \mathrm{BP}$, closer to the conclusions of Osborne (1979). In addition, the analysis of sedimentary cores from taro pondfields suggests that some markers of human occupation on Babeldaob might extend to the 6th millennium BP (Athens and Ward 1999, 2001; Welch 2001, 2002). The most recent radiocarbon results and their review show that people had colonized the rock islands, as well as Babeldaob, by earlier than 3000 BP (Clark and Wright 2003; Fitzpatrick 2002, 2003; Phear et al. 2003).

In beginning our archaeological research on Palau in 2000, we were aware that our initial focus upon the large structural features - comprising terraces, ditches, and crowns that are interpreted variously as defensive, domestic, and agricultural complexes (Wickler 2001a, 2002) —entailed grappling with the most difficult of dating problems in Palauan archaeology. Existing ${ }^{14} \mathrm{C}$ ages for these prominent features of the Palauan landscape were particularly diverse, even within the same structural element. While the inception of terracing and related hill-slope constructions was put generally at "the first century AD or perhaps a bit earlier" (Welch 2001:182), the associated ${ }^{14} \mathrm{C}$ ages ranged from about $3400 \mathrm{BP}$ up to about $800 \mathrm{BP}$, with clusters of dates in the ranges 1600-1500 BP and 1200-800 BP (Phear et al. 2003). Consequently, we sought to investigate potential sources of variation in ${ }^{14} \mathrm{C}$ ages.

As the structural sites were constructed in damp saprolitic clays, almost no bone or midden shell has survived, and that which does is highly degraded. Most ${ }^{14} \mathrm{C}$ samples were, or appeared to be, of charcoal. However, charcoal in these sites is dispersed and generally comminuted, and it can be confused with fragments of a common pottery fabric. This "thin blackware" has yet to be described in detail and its age is known only approximately, from several associated dates on charcoal, as about 2800-1500 BP (Welch 2001:180; 2002:166). It is a thin (2-7 mm thick), grog-tempered ware with a black core which is often heavily eroded. It is encountered commonly in the damp terrace clays as small pieces or grains of a soft, black substance, which in hand specimen is easily confused

${ }^{1}$ Corresponding author. Email: aja@coombs.anu.edu.au. 


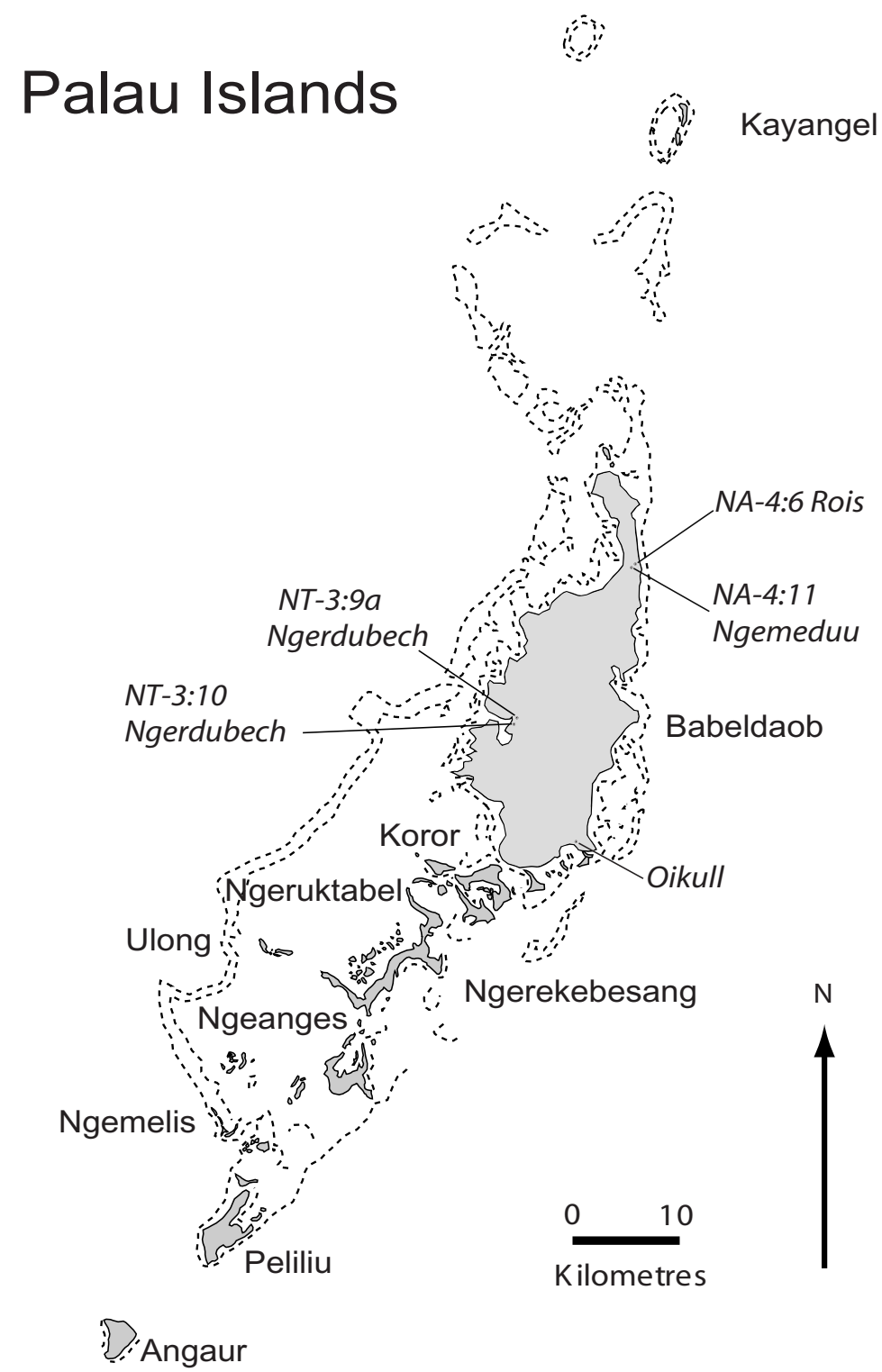

Figure 1 Palau, showing location of sites mentioned in the text

with wood charcoal. Many pieces bear a striking resemblance to the charred endocarp of coconut (Cocos nucifera). One matter to investigate, then, was whether some variation in the corpus of Palauan ${ }^{14} \mathrm{C}$ dates could have arisen from the inadvertent use of pottery samples.

The results of deliberate pottery dating show that use of this sample type is fraught with difficulties, as demonstrated by Kolic (1995) (see also Bollong et al. 1993), and has little to recommend it where more suitable materials are available. Pottery has been ${ }^{14} \mathrm{C}$ dated on several occasions in western Micronesia, initially by Taylor and Berger (1968) on sherds from Guam, later by Osborne (1979: 234-41) on sherds from Babeldaob and the rock island Aulong (Ulong) in Palau, and most recently 
by Beardsley and Basilius (2002) on charcoal extracted from the fabric of a painted bowl found in a burial cave in Palau.

Some of the results are plausible, but given that human settlement in Micronesia generally was not thought to extend beyond the late Holocene, Osborne (1979:234) concluded that his "sherd dates are all shockingly old, ranging from 8150 to 3320 radiocarbon years." He suggested that this might have arisen from ancient carbon in the clays used for pottery manufacture, and a modern sample of Palauan clay was then dated at $1900 \pm 400 \mathrm{BP}$, with which figure Osborne sought to calibrate his results. This approach is problematic, as Masse (1989) observed, but it highlighted the issue of what was producing anomalous ages in pottery and whether it or other sources of contamination were confined necessarily to that sample material, or indeed to archaeological contexts.

A particular source of potential contamination by old carbon occurs locally in the Babeldaob landscape in the form of soft lignite and dark gray organic clay within the kaolinitic Airai clay formation of upper Tertiary age, overlying the volcanic bedrock and saprolite. Indeed, kaolinitic Airai clay seen at three fairly extensive exposures (Nerassa, Oikull, Ulimang) was found to be flecked, commonly with black organic material, and to grade into dark gray organic clay overlying or underlying lignitic beds. The Airai clay is very suitable for pottery and is said to have been used in traditional Palauan manufacture near Oikull (Vince Blaiyok, personal communication). This is supported by Instrumental Neutron Activation Analysis (INAA) which identified Oikull and Ngimis as likely sources of clay used for making prehistoric pottery (Pavlish et al. 1986). Tiles were made from the Nerassa Island deposit of Airai clay by occupying Japanese during WWII. Considering that much of the clay is carbonaceous, it seems likely that ancient carbon could be retained in low-temperature pottery made from it.

Old-carbon contamination of archaeological materials could occur also if they had been infused by groundwater which was carrying organic compounds derived from the lignite, or if a site was built up of materials that included the lignite. In contrast, mobilization of organic compounds derived from today's soil could lead to young-carbon contamination. Contamination by both old and young carbon, either from lignitic sources or from soil charcoals of unknown age and derivation, could also occur, of course, through erosion and runoff into sedimentary basins. Athens and Ward $(1998,2001)$ noted this potential difficulty in the dating of sedimentary sequences used to reconstruct patterns of landscape and vegetational change on Palau.

Since lignite deposits and dispersed fragments in saprolites could be mistaken for charcoal incorporated in pottery or deposited in sedimentary basins, there is a significant possibility of confusion in Palauan ${ }^{14} \mathrm{C}$ dating. This paper describes our initial investigation of the problem and the implications of our results. We use pottery and charcoal samples from selected terrace sites to investigate the comparability of ${ }^{14} \mathrm{C}$ dating results and the sources of carbon contamination.

\section{METHODS}

\section{Sample Collection}

Excavations were renewed at several terrace sites already dated on multiple samples of charcoal. These were NT-3:9a, Japanese pits 1 and 2, and NT-3:10 (details of fieldwork in Wickler 2001b). There were also initial excavations on the crown of the Ngemeduu terrace site and at the Rois terraces (Phear 2004). All of the sites are remote from, or stand much higher in the landscape than, areas of lignite. The sites therefore are expected to have been uncontaminated by groundwater carrying dissolved old-carbon compounds. A carbon-bearing manganese nodule was collected from 
an exposure at Ngemeduu and specimens of lignite and organic clay were collected from the Airai clay deposits at Oikull and Ulimang.

Ngerdubech NT-3:9a. Research at this traditional stonework village had produced $13{ }^{14} \mathrm{C}$ dates (Liston et al. 1998:Table 61), most of them to the late 2nd millennium AD, as expected from the nature of the site. However, the village had been built partially on earlier cut-and-fill constructed terraces. Two defensive pits had been excavated by Japanese troops during WWII into the riser of one of those terraces. Trenches were excavated further into the terrace from both pits in 1997 (Wickler et al. 1997; Liston et al. 1998). Terrace fill layers were recorded and dated using material identified as coconut (Cocos nucifera) nutshell. Excavation trench TR-9 in Pit 1 dated to the 2nd millennium AD (Wk-5901, $280 \pm 100$ BP; Wk-5898, $570 \pm 80$ BP), while excavation trench TR-8 in Pit 2 produced similar dates for fill on the southern face of the trench (Wk-5902, $444 \pm 72$ BP; Wk-5903, $621 \pm 72 \mathrm{BP}$ ), and on the eastern face of the Japanese pit (Beta-100016, $910 \pm 70 \mathrm{BP}$ ). However, on the northern face of TR8, the base of the fill was dated as $2994 \pm 79$ BP (Wk-5904) according to Liston et al. (1998:Table 61).

In 2000, we re-faced the excavation trenches and cut test sections through the stratigraphy as $0.5-\mathrm{m}^{2}$ columns. In our view, the various fill layers recognized in earlier work can be regarded as a single stratigraphic unit of terrace fill deposits overlying undisturbed saprolitic clay (Wickler 2001b). We would expect that the terrace construction was of relatively limited duration and therefore that reliable ${ }^{14} \mathrm{C}$ dates would cluster together. We chose ${ }^{14} \mathrm{C}$ samples as noted in Table 1. In TR-9, our samples ANU-11405 (black pottery) and ANU-11391 (charcoal) came from points immediately adjacent to the sampling points for Wk-5901 and Wk-5898, respectively. ANU-11406 (black pottery) is from $0.2 \mathrm{~m}$ beneath the location of Wk-5901, and ANU-11855 (charcoal) is $0.4 \mathrm{~m}$ above the location of Wk-5898. In TR-8, ANU-11407 (black pottery) was located $0.3 \mathrm{~m}$ above the location of Wk-5904.

Ngerdubech NT-3:10. About 35 m northeast of NT-3:9a, TR-1 was excavated on a higher terrace and crown construction, designated NT-3:10 (Liston et al. 1998). TR-1 was $2.2 \mathrm{~m}$ deep and 3 dates were produced. From near the base of cultural deposits came Wk-5926 (2809 \pm 72 BP) on charcoal that may be from the secondary forest tree, Macaranga caroliensis. From $1.65 \mathrm{~m}$ came Wk-6469 $(2334 \pm 60 \mathrm{BP})$ on charcoal from palm and unidentified taxa, and from $0.9 \mathrm{~m}$ came Wk-6468 $(2717 \pm 58)$ on unidentified charcoal (Liston 1999). We re-excavated TR-1 in 2000 and took samples from as low as material could be obtained, 1.6 to $1.7 \mathrm{~m}$ (ANU-11408, black pottery, and ANU-11837, charcoal). These are adjacent to the location for Wk-6469. ANU-11782 was collected from a road cutting exposure $20 \mathrm{~m}$ south of the site and $1 \mathrm{~m}$ below the surface.

Rois NA-4.6. Excavation in 2001 of a terrace site at the Rois burial complex (NA-4.6) by Phear (2004) produced some additional samples of black pottery. A $3.2 \times 0.5-\mathrm{m}$ trench was excavated on a lower terrace in the complex (TR-4). Black pottery samples were collected at $0.8-0.9 \mathrm{~m}$, Layer V (ANU-11582A, ANU-11583A) within terrace fill material. Results on these cannot be compared directly with charcoal dates from the same excavation, but elsewhere in the constructed features of the same terrace complex, there are dates of $2015 \pm 68$ BP (Wk-5920) on a sample of ironwood (Casuarina litorea) charcoal; $1772 \pm 67 \mathrm{BP}$ (Wk-5922) on a charcoal sample, possibly of mangrove (Rhizophora sp.); and $1723 \pm 68$ BP (Wk-5889) on charred grasses (Liston 1999).

Ngemeduu NA-4:11. This crown and terrace complex, also excavated by Phear (2004), disclosed a cultural stratigraphy extending over $4 \mathrm{~m}$ deep (Phear 2003). ANU-11658 is a charcoal sample from $4 \mathrm{~m}$ deep in the lowest cultural level (Layer VIII) in trench TR1a, which was excavated on the crown. ANU-11659 is a charcoal sample from a posthole at 1.3 to $1.7 \mathrm{~m}$ at the base of the cultural stratigraphy in trench TR1i, which was located on the terrace that encircles the crown. Black pottery sample ANU-11783 is also from this trench, at $0.6 \mathrm{~m}$ depth. 
Non-archaeological samples. ANU-11780 is a sample of lignitic Airai clay from Oikull, taken at $1 \mathrm{~m}$ deep in a roadside exposure at lat $7^{\circ} 22.459^{\prime} \mathrm{N}$, long $134^{\circ} 35.001^{\prime} \mathrm{E}$. ANU-11781 is a soft manganese nodule from the Ngemeduu excavation, at $0.6 \mathrm{~m}$ depth.

\section{Sample Treatment}

Samples were identified at, and pretreated in, the Australian National University Radiocarbon Laboratory (Canberra) in 3 ways for ${ }^{14} \mathrm{C}$ determination: i) as bulk samples (water-washed and dried), ii) as alkali-soluble extracts $(2 \mathrm{~N} \mathrm{NaOH})$, and iii) as $\mathrm{ABA}$ (acid-base-acid) residues. The $\mathrm{NaOH}$ extracts were intended to isolate soluble organic compounds that had entered a sample from groundwater. The ABA treatment usually (but not always) removes many such compounds, and the residual carbon in these preparations was expected to be dominantly that which was present when the sample was formed (in the case of charcoal) or manufactured (in the case of pottery).

According to the amount of carbon in a preparation, the ${ }^{14} \mathrm{C}$ content was measured either by liquid scintillation radiometry (typically samples with $>0.2 \mathrm{~g} \mathrm{C}$ ) or, when carbon yield was very small, by accelerator mass spectrometry (AMS). The percentage of primary carbon present in the original specimen also was estimated by dividing the weight of carbon present after ABA treatment by the original sample dry weight.

\section{RESULTS}

Results are listed in Table 1. It is apparent that while our charcoal samples were not identified to taxa, they produced results which are very comparable with those obtained by earlier researchers on the specific sites, and on terrace sites in general: compare ANU-11855 and ANU-11391 with Wk5901 and Wk-5898 (Liston et al. 1998:Table 61); also ANU 11837 with Wk-6469 (Liston 1999). There are several potential anomalies, noted below, but with those exceptions it can be said that the charcoal dates on Palauan terraces provide a quite consistent chronology against which to measure dates on pottery fabric. Here, the differences are very marked indeed, as we expected, and they exist both between the black pottery and charcoal samples and within the group of black pottery samples. What causes these effects?

In terms of primary carbon content, the archaeological samples divide into 2 groups: charcoal, with relatively high primary carbon (ANU-11658, ANU-11659), and black pottery, with a low percentage of primary carbon. The dated clay sample from Oikull and the manganese nodule from Ngemeduu also had low percentages of carbon. In terms of apparent ${ }^{14} \mathrm{C}$ ages, the results show a more complex distribution, but the data set indicates that at least 2 sources of contamination potentially may have affected any given sample, one being ancient carbon and the other being relatively young carbon.

Evidence for an ancient carbon source is most apparent in the ABA preparations of black pottery samples, several of which are between 10,000 and 15,000 BP, far exceeding all estimates of the earliest date of occupation of Palau. If accurate, they would be amongst the earliest dates for pottery anywhere in the world. The result of 29,090 BP (ANU-11780) from the putative pottery clay source at Oikull suggests that the ancient source was carbon in the original clay from which the pottery was made. Evidence for a source of young, mobile carbon is seen in the result of $1390 \mathrm{BP}$ (ANU-11781) from the $\mathrm{NaOH}$ extract from the manganese nodule, which itself would have contained no primary carbon. Evidence that samples may contain mixtures of these 2 sources is revealed by the difference between $\mathrm{NaOH}$ extracts and $\mathrm{ABA}$ residues from black pottery: the $\mathrm{NaOH}$ extract, which is expected to carry the younger contaminant, gives a lesser age than the $\mathrm{ABA}$ residue in each case where the 2 
Table $1{ }^{14} \mathrm{C}$ ages and contextual data for samples in the comparative dating project, Palau. ANU-11391 B1 is an older sample that was not tested for carbon content.

\begin{tabular}{lclrlll}
\hline Lab nr & Provenance & Material & \multicolumn{1}{l}{ Yr BP } & \multicolumn{1}{l}{$\delta^{13} \mathrm{C}$} & Fraction & \% C at ABA \\
\hline Ngerdubech & NT-3:9a Pit 1 & TR-9 & & & & \\
ANU-11391 B-1 & $70-80 \mathrm{~cm}$ & Charcoal & $600 \pm 60$ & $-26.0 \pm 2.0$ & Insoluble & n.d. \\
ANU-11391 B-2 & $70-80 \mathrm{~cm}$ & Charcoal & $570 \pm 40$ & $-24.0 \pm 2.0$ & Soluble & - \\
ANU-11405 B-1 & $70-80 \mathrm{~cm}$ & Black pottery & $2880 \pm 130$ & $-25.9 \pm 0.2$ & Insoluble & 1.5 \\
ANU-11405 B-2 & $70-80 \mathrm{~cm}$ & Black pottery & $1230 \pm 160$ & $-25.9 \pm 0.2$ & Soluble & - \\
ANU-11406 B-1 & $80-90 \mathrm{~cm}$ & Black pottery & $5120 \pm 140$ & $-26.0 \pm 0.2$ & Insoluble & 1.5 \\
ANU-11406 B-2 & $80-90 \mathrm{~cm}$ & Black pottery & $3610 \pm 160$ & $-26.0 \pm 0.2$ & Soluble & - \\
ANU-11855 & $70-80 \mathrm{~cm}$ & Charcoal & Modern & $-24.0 \pm 2.0$ & Whole & - \\
Ngerdubech & NT-3:9a Pit 2 & TR-8 & & & & \\
ANU-11407 B-1 & $60-70 \mathrm{~cm}$ & Black pottery & $9630 \pm 260$ & $-26.9 \pm 0.2$ & Insoluble & 0.6 \\
ANU-11407 B-2 & $60-70 \mathrm{~cm}$ & Black pottery & $6230 \pm 160$ & $-26.9 \pm 0.2$ & Soluble & - \\
Ngerdubech & NT-3:10 & TR-1 & & & & \\
ANU-11408 B-1 & $160-170 \mathrm{~cm}$ & Black pottery & $10,870 \pm 190$ & $-26.5 \pm 0.2$ & Insoluble & 1.2 \\
ANU-11408 B-2 & $160-170 \mathrm{~cm}$ & Black pottery & $7450 \pm 180$ & $-26.5 \pm 0.2$ & Whole & - \\
ANU-11782 & $100 \mathrm{~cm}$ & Black pottery & $7880 \pm 160$ & $-25.4 \pm 0.2$ & Whole & 1.3 \\
ANU-11837 & $160-170 \mathrm{~cm}$ & Charcoal & $2060 \pm 210$ & $-17.6 \pm 2.0$ & Whole & - \\
Rois Terrace & NA-4:6 & TR-4 & & & & \\
ANU-11582 A & $80 \mathrm{~cm}$ & Black pottery & $13,260 \pm 190$ & $-26.4 \pm 0.2$ & Whole & 3.9 \\
ANU-11583 A & $90 \mathrm{~cm}$ & Black pottery & $15,240 \pm 290$ & $-27.1 \pm 0.1$ & Whole & 4.4 \\
Ngemeduu & NA-4:11 & & & & \\
ANU-11658 & $400 \mathrm{~cm}$ & Charcoal & $1510 \pm 200$ & $-25.4 \pm 0.2$ & Whole & 15 \\
ANU-11659 & $130-170 \mathrm{~cm}$ & Charcoal & $2140 \pm 220$ & $-25.4 \pm 0.2$ & Whole & 39 \\
ANU-11783 & $60 \mathrm{~cm}$ & Black pottery & $10,580 \pm 130$ & $-26.1 \pm 0.1$ & Whole & 0.9 \\
Non-archaeological samples & & & & & \\
ANU-11780 & $100 \mathrm{~cm}$ & Lignitic clay & $29,090 \pm 520$ & $-27.0 \pm 0.1$ & Whole & 0.3 \\
ANU-11781 & $60 \mathrm{~cm}$ & Mn nodule & $1390 \pm 200$ & $-27.8 \pm 0.1$ & Soluble & 0.1 \\
\hline
\end{tabular}

fractions were prepared (ANU-11405, ANU-11406, ANU-11407). A similar difference is seen in ANU-11408, where the bulk sample gave a lesser age than the ABA preparation.

The results also indicate that $\mathrm{ABA}$ pretreatment fails to remove all the contaminant that enters as mobile carbon. If, at the time of firing, the pottery contained only Tertiary-age carbon from the Airai clay, then all ABA preparations should give "infinite" (or "greater than") ${ }^{14} \mathrm{C}$ ages (sensu Stuiver and Polach 1977). In fact, all the black pottery ABA preparations gave finite ages, the lowest being only $2880 \mathrm{BP}$ (ANU-11405); indeed, the ABA preparation from Airai clay gave a finite age of 29,090 BP (ANU-11780). In terms of two-component mixing, the apparent age depends not only on the amount of ancient contaminant retained in the pottery, but also on the age-distortion from residual younger contaminant that has resisted extraction in the ABA pretreatment.

It seems likely that neither of these preparations can be measured because the amount of ancient carbon in the Airai clay is highly variable, the proportion that survives firing has yet to be determined, the efficacy of ABA with these materials has yet to be determined, and the age and quantity of residual contaminants will remain unknown. The possibility that carbon entered at the time of firing or when a pot was in use only confounds the issue further.

\section{DISCUSSION AND CONCLUSIONS}

The question confronting field scientists after receiving a set of conflicting ${ }^{14} \mathrm{C}$ determinations is which, if any, of the results represent accurate dates. The answer must be discovered from the logic of data from the field, the laboratory, and from the samples themselves. In the present case, none of 
the black pottery results can be regarded as indicating the age of a specimen or its time of burial. Pottery, being derived from clay, contains carbon only as a contaminant. Where ancient carbon within the clay itself survives firing, which on the evidence is the case here, and where young carbon taken up by the pottery has not been fully removed in pretreatment, which again evidently has happened here, then to attempt to infer any chronological meaning is all but futile.

Having eliminated the black pottery, it remains to ask whether charcoal dates are reliable in a context where residues of once-mobile carbon are not fully removed in ABA pretreatment. The carbon content of the specimen is a useful guide to reliability. This can be measured using EDXA; Clark (2004) found that elemental analysis of Palauan archaeological pottery and charcoal produced very similar carbon measurements to those reported here on samples of pottery and charcoal. But it is probably easier to measure carbon content during the ${ }^{14} \mathrm{C}$ dating process, as here. Whereas the black pottery samples contain only a percent or two of carbon, for the charcoal samples the carbon remaining at $\mathrm{ABA}$ ranges from 10 to $40 \%$ (this is the range for all macroscopic charcoal samples from Palau dated at ANU, of which only two are listed in Table 1). Experiments on carbon from charcoal, using more aggressive oxidative pretreatment (ABOX: Bird et al. 2000; see also Gillespie et al. 1992), show that the ABA fraction is dominantly comprised of original carbon, and that age distortion arising from the failure of $\mathrm{ABA}$ to remove young contaminants from it is very difficult to detect in charcoal that is only a few thousand years old. In short, ABA charcoal ages from Palau are expected to be reliable. On that basis, we conclude provisionally that a critical assessment of ${ }^{14} \mathrm{C}$ determinations (Phear et al. 2003) indicates that monumental earthworks cluster in the Palauan sequence in the period $1600-800 \mathrm{cal} \mathrm{BP}$.

There remains the problem of sample identification. Black pottery fragments excavated from Palau often resemble charcoal fragments: both can be soft, rounded, and black, and the smaller the fragment the more readily may one be taken for the other. Thus, to minimize the likelihood of error, in addition to the usual tests of stratigraphic consistency and age reproducibility, the carbon content should be measured at the time of dating and, where the content is low, the ${ }^{14} \mathrm{C}$ result must be taken as something other than sample age. Carbon content may be a more useful measure of origin than attempted wood identification for very small samples, although microscopic, including SEM, examination could be equally useful, if a more elaborate approach. Carbon content analysis ought perhaps to be adopted, retrospectively, for those samples that, although regarded as charcoal, produced quite anomalous ages. Such examples of relevance to the present cases would be Wk-5904 (above) and Wk-5900 (9240 \pm 68 BP), also from site NT-3:9a, for which Liston et al. (1998) suggested the possibility of lignite contamination.

A further implication of this issue lies in the dating of horizons of significant change in cores from sedimentary basins. The potential problems arising from carbon contamination, due to lignite, have been canvassed by Athens and Ward $(1998,1999)$. Welch (2002:170) suggests that at least some apparent charcoal in core samples might actually be lignite and notes that tests to distinguish between these materials when they are fine-grained (using sulphur content, Athens and Ward 1999: 102) have proven, so far, inconclusive. One important instance in which the possibility of carbon contamination is worth further consideration is the Ngerchau core (Athens and Ward 2001) in which 8 grains of pollen from a probable introduced cultigen, the giant swamp taro Cytopsperma chamissonis, were dated to the 5th to 6th millennia BP and held as "evidence [which] appears to be the 'smoking gun' establishing human agency at a very early time" (Athens and Ward 2001:172).

There are questions about the contextual evidence, such as the absence of any rise in charcoal or disturbed ground indicators associated with the lowest occurrence of Cytosperma pollen (Athens and 
Ward 1999:102), and also about the ${ }^{14} \mathrm{C}$ dating. The top sections of this core date to less than $3000 \mathrm{BP}$ and the Cytosperma pollen is in the lower sections, for which $5{ }^{14} \mathrm{C}$ dates, all on unidentified peat and wood samples, are virtually indistinguishable from the top (3840 $\pm 90 \mathrm{BP}$, Beta-127286, at $2.0 \mathrm{~m}$ depth) to the bottom (4008 $\pm 57 \mathrm{BP}, \mathrm{Wk}-6721$, at $5.4 \mathrm{~m}$ depth). Athens and Ward (2001) argue that the sequence represents very rapid early accumulation, followed by a sedimentary unconformity, but the same pattern could be produced by carbon contamination, especially of the samples near the top of the peat, where a 6th date was anomalously old (5203 $\pm 62 \mathrm{BP}$, Wk-6414, at $2.45 \mathrm{~m})$. The matter must remain in doubt until the carbon content of the samples has been measured. The Ngerchau core is now being re-examined in a joint project between the International Archaeological Research Institute Inc. (IARII) and the Australian National University.

At present, there is a significant discrepancy between a paleoenvironmental inference of settlement in western Micronesia by about 4800-4500 BP (Wickler 2001a) and archaeological results that do not extend currently beyond about 3500-3000 cal BP (Clark 2004). The magnitude of the discrepancy, and the potential for dating materials in both Palauan contexts to be contaminated by environmental sources of carbon, requires further systematic investigation of the kind advocated here before either "long" or "short" prehistoric occupation chronologies can be accepted with confidence.

\section{ACKNOWLEDGMENTS}

We thank Stephen Athens, Stephen Wickler (University of Tromsø), Jolie Liston (IARII), and Vince Blaiyok (IARII) for their guidance in the Palauan fieldwork, Vicky Kanai, Rita Olsudong, and the Governor of Ngaraard for governmental support. The community bai in Ngeklau were generous in providing accommodation, and the Research School of Pacific and Asian Studies (ANU) likewise in funding the project.

\section{REFERENCES}

Athens JS, Ward JV. 1998. The Holocene paleoenvironment of Palau. In: Intensive Archaeological Survey for the Palau Compact Road, Babeldaob Island, Palau. Historic Preservation Investigations, Phase II. Volume IV. Honolulu: International Archaeological Research Institute, Inc.

Athens JS, Ward JV. 1999. Archaeological Data Recovery for the Compact Road, Babeldaob Island, Republic of Palau. Volume IV, The Holocene Paleoenvironment of Palau. Honolulu: International Archaeological Research Institute, Inc.

Athens JS, Ward JV. 2001. Palaeoenvironmental evidence for early human settlement in Palau: the Ngerchau core. In: Stevenson CM, Lee G, Morin FJ, editors. Pacific 2000. Proceedings of the Fifth International Conference on Easter Island and the Pacific. Los Osos, California: Easter Island Foundation. p 164-77.

Beardsley FR, Basilius U. 2002. Sengall Ridge, Belau: burials, spirit walks and painted pottery. Indo-Pacific Prehistory Association Bulletin: Melaka Papers 6: 147-51.

Bird MI, Turney CSM, Fifield LK. 2003. Radiocarbon dating of organic- and carbonate-carbon in Genyornis and Dromaius eggshell using stepped combustion and stepped acidification. Quaternary Science Reviews 22:1805-12.
Bollong CA, Vogel JC, Jacobson L, van der Westhuizen WA, Sampson CG. 1993. Direct dating and identity of fibre temper in pre-contact Bushman (Basarwa) pottery. Journal of Archaeological Science 20:41-55.

Clark G. 2004. Radiocarbon dates from the Ulong site in Palau and implications for western Micronesian prehistory. Archaeology in Oceania 39:26-33.

Clark G, Wright D. 2003. The colonisation of Palau: preliminary results from Angaur and Ulong. In: Sand C. editor. Pacific Archaeology: Assessments and Prospects. Les Cahiers de l'Archéologie en NouvelleCalédonie. Number 5. Nouméa: Museum of New Caledonia. p 85-94.

Fitzpatrick SM. 2002. AMS dating of human bone from Palau: new evidence for a pre-2000 BP settlement. Radiocarbon 44(1):217-21.

Fitzpatrick SM. 2003. Early human burials in the western Pacific: evidence for a c. 3000 year old occupation on Palau. Antiquity 77:719-31.

Gillespie R, Prosser IP, Dlugokencky E, Sparks RJ, Wallace G, Chappell JMA. 1992. AMS dating of alluvial sediments on the southern tablelands of New South Wales, Australia. Radiocarbon 34(1):29-36.

Kolic ED. 1995. Direct radiocarbon dating of pottery: selective heat treatment to retrieve smoke-derived carbon. Radiocarbon 37(2):275-84 
Liston J. 1999. Archaeological Data Recovery for the Compact Road, Babeldaob Island, Republic of Palau. Historic Preservation Investigations, Phase II. Volume V: Lab Analyses, Syntheses and Recommendations. Honolulu: International Archaeological Research Institute, Inc.

Liston J, Mangieri TM, Grant D, Kaschko MW, Tuggle, HD. 1998. Archaeological Data Recovery for the Compact Road, Babeldaob Island, Republic of Palau. Historic Preservation Investigations, Phase II. Volume II: Fieldwork Reports. Honolulu: International Archaeology Research Institute, Inc.

Masse WB. 1989. The Archaeology and Ecology of Fishing in the Belau Islands, Micronesia. Part 1 and Part 2. University Microfilms International. Ann Arbor: Michigan.

Masse WB. 1990. Radiocarbon dating, sea-level change and the peopling of Belau. Micronesica Supplement 2: 213-30.

Osborne D. 1979. Archaeological test excavations in the Palau Islands 1968-1969. Micronesica Supplement 1.

Pavlish LA, Hancock RG, Snyder D, Lucking L. 1986. INAA study of pottery from Palau. In: Olin J, Blackman MJ, editors. Proceedings of the 24th International Archaeometry Symposium. Washington DC: Smithsonian Institution Press. p 383-7.

Phear S. 2003. Painted pottery in Palau: new evidence challenges past interpretations. Antiquity 77(296): http://antiquity.ac.uk/ProjGall/phear/phear.html.

Phear S. 2004. The monumental earthworks of Palau [PhD dissertation]. Canberra: Australian National University.

Phear S, Clark G, Anderson A. 2003. A radiocarbon chronology for Palau. In: Sand C, editor. Pacific Archaeology: Assessments and Prospects. Les Cahiers de l'Archéologie en Nouvelle-Calédonie Number 15. Nouméa: Museum of New Caledonia. p 241-9.

Stuiver M, Polach HA. 1977. Discussion: reporting of ${ }^{14} \mathrm{C}$ data. Radiocarbon 19(3):355-63.

Taylor RE, Berger R. 1968. Radiocarbon dating of the or- ganic portion of ceramic and wattle-and-daub house construction materials of low organic content. American Antiquity 53:363-6.

Welch DJ. 2001. Early upland expansion of Palauan settlement. In: Stevenson CM, Lee G, Morin FJ, editors. Pacific 2000. Proceedings of the Fifth International Conference on Easter Island and the Pacific. Los Osos, California: Easter Island Foundation. p 164-77.

Welch DJ. 2002. Archaeological and palaeoenvironmental evidence of early settlement in Palau. Bulletin of the Indo-Pacific Prehistory Association 22:161-73.

Wickler S. 1998. Research summary. In: Wickler S, Welch DJ, Tomonari-Tuggle MJ, Liston J, Tuggle HD, editors. Intensive Archaeological Survey for the Palau Compact Road, Babeldoab Island, Palau. Historic Preservation Investigations, Phase I. Volume 1: Scope, Background, Results, Evaluation and Recommendations. Honolulu: International Archaeological Research Institute, Inc.

Wickler S. 2001a. The colonization of western Micronesia and early settlement of Palau. In: Stevenson CM, Lee G, Morin FJ, editors. Pacific 2000. Proceedings of the Fifth International Conference on Easter Island and the Pacific. Los Osos, California: Easter Island Foundation. p 185-96.

Wickler S. 2001b. Preliminary field report for the ANUTromsø Museum Palau 2000 Project, Babeldaob, Republic of Palau, August-September 2000. Tromsø University Museum.

Wickler S. 2002. Terraces and villages: transformations of the cultural landscape in Palau. In: Ladefoged TN, Graves MW, editors. Pacific Landscapes: Archaeological Approaches. Honolulu: Easter Island Foundation. p 63-96.

Wickler S, Addison DJ, Kashko MW, Dye TS. 1997. Intensive Archaeological Survey for the Palau Compact Road, Babeldoab Island, Palau. Volume II: Area Survey Reports. Honolulu: International Archaeological Research Institute, Inc. 